УДК [342.951:314.74] (477)

DOI https://doi.org/10.32837/pyuv.v2i3(28).351

\author{
С. Г. Божок \\ кандидат юридичних наук, \\ старший викладач кафедри адміністративного права \\ та адміністративного процесу \\ Херсонського факультету \\ Одеського державного університету внутрішніх справ \\ В.С. Медведєва \\ студентка III курсу \\ Херсонського факультету \\ Одеського державного університету внутрішніх справ
}

\title{
ПРОФЕСІЙНА ОСВІТА ПОЛІЦЕЙСЬКОГО: НАПРЯМИ РЕФОРМУВАННЯ (ВДОСКОНАЛЕННЯ)
}

На сучасному етапі реформування системи Мiністерства внутрішніх справ (далі - МBC), у тому числі системи відомчої освіти, яка відображає стан розвитку суспільства та пов'язані з ними соціально-економічні зміни, необхідним складником є якісна підготовка фахівців у тому числі й для правоохоронних органів.

Орієнтація України на Європейські стандарти формує позитивні тенденції до розроблення нових стандартів підготовки фахівців. Однак в умовах реформування системи МВC і залишення «неподоланих» проблем з минулого «міліції» (недостатне фінансування та матеріально-технічне забезпечення, низька соціальна захищеність працівників поліції) актуальними є питання вдосконалення системи підготовки працівників поліції в сучасних умовах [1, с. 53].

Основною ланкою такої підготовки є система відомчих вищих навчальних закладів системи MBC України, які, у свою чергу, потребують постійного оновлення матеріально-технічної бази, удосконалення методичного забезпечення, підвищення фінансування й залучення висококваліфікованих науково-педагогічних працівників для підвищення якості освіти поліцейського.

Необхідно підкреслити також, що в умовах загострення криміногенної ситуації в державі особливого значення набувають питання професійної підготовки поліцейських до службової діяльності. Нестабільність соціально-економічних відносин, переоцінка цінностей у різних сферах суспільного життя відображаються й у діяльності поліцейського.

Професія «поліцейський» є однією з найскладніших професій сучасного суспільства, так як вимагає здатності з високою ефективністю вирішувати професійні завдання, що пов'язані з ризиком для життя, за браком часу максимально реагувати на ту чи іншу ситуацію з високим рівнем відповідальності за свої дії. Діяльність працівників поліції безпосередньо спрямована на захист особи, іï прав і свобод, охорону громадського порядку і громадської безпеки, на протидію злочинності. Поряд із цим сучасне суспільство вимагає від працівника поліції високого культурного рівня, освіченості, здатності до самоосвіти й самовдосконалення, уміння застосовувати свої знання в різних сферах правоохоронної діяльності, що об'єктивно потребує переосмислення чинної системи підготовки кадрів для поліції [2, с. 54].

3-поміж іншого, якими б досконалими не були закони в державі, технічне оснащення поліції, саме людський фактор, особиста культура та світогляд поліцейського, мотиви вчинків і його реальні соціальні дії визначають ступінь успіху поліцейської діяльності. Із цього приводу варто виділяти три основні складники: мотивацію службової діяльності, набуття практичних навичок i культуру поведінки. Внутрішня мотивація є вирішальною обставиною, яка перетворює людину на професіонала, зокрема поліцейського, при цьому потрібно заохочувати й розвивати такі «духовні» установки особистості, як професійне покликання, почуття самоповаги та гордості професіонала, нарешті, патріотизм.

Пріоритетні напрями розвитку відомчої освіти на сучасному етапі державотворення в роботах висвітлювали такі вітчизняні вчені, як С.М. Алфьоров, Т.Г. Гриця, О.Є. Користін, Д.О. Поштарук, В.В. Сокуренко, В.В. Чернєй, С.С. Чернявський та інші.

Загальновідомий факт полягає в тому, що традиційні підходи до підготовки працівників правоохоронних органів неповною мірою забезпечують необхідну якість і професійну компетентність кваліфікованих кадрів поліції. I тому можемо зробити висновок про наявність об'єктивно існуючого протиріччя між вимогами, що зростають, сучасного суспільства до діяльності поліції і традиційною системою підготовки поліцейських. Основною проблемою поліцейської освіти залишається необхідність реформування відомчих 
вищих навчальних закладів, які підпорядковані MBC. Наприклад, один із провідних відомих закладів, Національна академія внутрішніх справ України, а також ще шість вищих навчальних закладів при МВС здійснюють підготовку як юристів (вища юридична освіта необхідна не всім категоріям поліцейських, але, скажімо, для слідчого вона є обов'язковою), так і психологів, а також здійснюють підготовку аспірантів і докторантів. Разом із цим для роботи в поліції в широкому сенсі цього слова підходить будь-яка вища юридична освіта, отримана в будь-якому вищому навчальному закладі. А для того, щоб дати здібному кандидатові на посаду поліцейського, який перед цим успішно пройшов конкурсний відбір, певні специфічні знання в галузі його майбутньої діяльності, достатньо проходження ним спеціального інтенсивного курсу навчання в закладі системи МВС від шести місяців до одного року.

Метою статті є визначення актуальних напрямів реформування відомчої освіти МВС загалом і пріоритетних напрямів підготовки поліцейських зокрема.

Стратегія розвитку органів системи МВС України до 2020 року визначила одним із напрямів зосередження ресурсів і зусиль у межах пріоритетів державної політики у сфері внутрішніх справ i розвитку системи МВС [6].

Як слушно зазначив Олексій Тахтай, державний секретар МВС, «відомчі вищі навчальні заклади відіграють значну роль у процесі реформування правоохоронної системи. Ідеться як про участь у нормотворчій роботі, так і про підготовку працівників патрульної поліції та перекваліфікацію поліцейських» .

Згідно з прийнятими Законами України «Про вищу освіту» від 01.07.2014 № 1556-VII, «Про Національну поліцію» від 02.07.2015 № 580-VIII, значну роль відіграють навчальні заклади системи МВC, які посідають своє місце в національно-правовій системі [3].

Досвід передових зарубіжних країн свідчить про те, що ефективна професійна підготовка правоохоронців обов'язково передбачає психологічний складник. Ефективний поліцейський має не тільки володіти спеціальними професійними знаннями й уміннями, а й бути психологічно готовим до дій в особливих та екстремальних умовах, комунікації з різними категоріями громадян, застосування фізичної сили та спецзасобів, швидкого реагування на події в умовах дефіциту часу й ризику тощо. Тому важливим напрямом підвищення ефективності функціонування правоохоронного органу є забезпечення психологічної підготовки поліцейських до умов професійної діяльності. Однак поки що нема достатнього досвіду щодо професійної психологічної підготовки поліцейських до діяльності; досі не розроблено відпо- відне нормативно правове забезпечення такої підготовки поліцейських.

Так, зокрема, у Законі України «Про Національну поліцію» нічого не говориться про систему психологічної підготовки поліцейських.

Стаття 72 Закону України «Про Національну поліцію» визначає систему професійного навчання поліцейських, яка складається з чотирьох напрямів:

1. Первинна професійна підготовка.

2. Підготовка у вищих навчальних закладах зі специфічними умовами навчання.

3. Післядипломна освіта.

4. Службова підготовка [3].

Однак дослідження багатьох авторів показують, що поліцейському потрібно мати необхідні для роботи професійно важливі індивідуально-психологічні якості, серед яких особливо важливими є сила й лабільність нервової системи, сміливість, стресостійкість, комунікабельність, лідерські якості, достатньо високий інтелект і креативність тощо [1]. Подібні індивідуальні особливості необхідно враховувати під час професійного відбору кадрів до поліції, не менш важливо постійно розвивати й удосконалювати різні компоненти психологічної готовності поліцейських до діяльності в процесі здійснення спеціальної професійної психологічної їх підготовки.

Проте чинна законодавча та нормативно-правова база діяльності Національної поліціїУкраїни не дає змоги повною мірою реалізувати актуальні завдання професійної психологічної підготовки поліцейських. Аналіз нормативно-правової бази й останніх досліджень, присвячених питанням професійної підготовки поліцейських і психологічної роботи в Національній поліції України, показує, що головними документами, які регламентують питання організації та проведення професійної та службової підготовки поліцейських, є Закон України «Про Національну поліцію» від 02.07.2015, Постанова Кабінету Міністрів України «Про затвердження Положення про Національну поліцію» від 28.10.2015 № 877 [4], а також Наказ МВС України «Про затвердження Положення про організацію службової підготовки працівників Національної поліції України» від 26.01.2016.

Необхідно відмітити також, що вітчизняні науковці надають великого значення розробленню проблематики психологічної підготовки поліцейських і проблем психологічного забезпечення діяльності МВС. Проведено чимало наукових досліджень i розроблено навчально-методичні, практичні посібники й рекомендації для поліцейських, керівників підрозділів поліції, психологів і працівників кадрових апаратів, які спрямовані на здійснення психологічного забезпечення діяльності Національної поліції. 
У визначенні мети поліцейської освіти дискусійним залишається питання, давати працівникам поліції повноцінну освіту або ж готувати вузьких фахівців у тій чи іншій сфері поліцейської діяльності. На думку німецького дослідника Пітера Дома, для поліції необхідно готувати й фахівців широкого профілю, і фахівців вузької спеціалізації. Загальновизнано, що нині в поліцейській діяльності котирується не горезвісна робоча сила, а працівник із високим рівнем освіченості, вихованості, професійної навченості, сукупність чого й формує професіоналізм.

Наказом МВС України від 26.01.2016 № 50 затверджено Положення про організацію службової підготовки працівників Національної поліції України [5]. Останнє визначає види службової підготовки, до яких належать:

1) функціональна підготовка - комплекс заходів, спрямований на набуття й удосконалення поліцейським знань, умінь і навичок у сфері нормативно-правового забезпечення службової діяльності, необхідних для успішного виконання ним службових обов'язків;

2) загальнопрофільна підготовка - комплекс заходів, спрямованих на набуття й удосконалення поліцейським умінь і навичок практичного застосування теоретичних знань щодо формування готовності до дій у ситуаціях різних ступенів ризику, а також надання домедичної допомоги в процесі виконання службових завдань;

3) тактична підготовка - комплекс заходів, спрямований на набуття й удосконалення поліцейським навичок практичного застосування теоретичних знань щодо правильного оцінювання конкретних подій із подальшим прийняттям правомірних рішень і психологічної готовності до дій у ситуаціях різних ступенів ризику;

4) вогнева підготовка - комплекс заходів, спрямований на вивчення поліцейським основ стрільби з вогнепальної зброї, правомірного ії̈ застосування й удосконалення навичок безпечного поводження з нею, швидкісної та влучної стрільби по нерухомих і рухомих цілях, із різних положень, в обмежений час, у русі тощо;

5) фізична підготовка - комплекс заходів, спрямований на формування й удосконалення рухових умінь і навичок, розвиток фізичних якостей і здібностей поліцейського 3 урахуванням особливостей його професійної діяльності.

Деякі види, наприклад, вогнева й тактична підготовки, передбачають психологічний складник. Так, у розглядуваному Положенні зафіксовано, що «заняття 3 вогневої підготовки організовуються та проводяться в навчальних групах за місцем служби, на навчальних зборах 3 обов'язковим урахуванням рівня підготовленості і психологічних якостей поліцейських». Тактична підготовка передбачає «набуття і вдосконалення психологіч- ної готовності поліцейських до дій у ситуаціях різних ступенів ризику»; «набуття та вдосконалення поліцейських навичок щодо формування морально-психологічної стійкості до виконання службових завдань в особливих умовах». Проте зазначеним Положенням не визначено форми, методи, технології та засоби вирішення завдань, пов'язаних із психологічним складником службової підготовки поліцейських.

На нашу думку, з метою докорінного поліпшення якості психологічної підготовки та психологічноїроботивпідрозділах НаціональноїполіціїУкраїни доцільно доповнити перелік видів службової підготовки, зафіксованих у Положенні про організацію службоової підготовки працівників Національної поліції України, затвердженому Наказом МВC від 26.01.2016 № 50, таким видом, як професійна психологічна підготовка поліцейських [5].

Досвід діяльності поліцій зарубіжних країн свідчить про те, що вона являє собою комплекс організаційних і психологічних заходів, спрямованих на формування й розвиток у поліцейських професійно важливих якостей. Професійна психологічна підготовка має на меті розвиток загальних і спеціальних професійних здібностей, знань і вмінь поліцейських і формування системної якості поліцейського - психологічної готовності особистості до професійної діяльності. Саме психологічна готовність $е$ кінцевим результатом психологічної підготовки та являє собою стійкий довготривалий стан особистості, який характеризується мобілізацією всіх психофізіологічних ресурсів організму, наявністю комплексу мотивів, знань, умінь, навичок та індивідуальних якостей, які забезпечують ефективність виконання певної діяльності. Психологічна готовність є передумовою будь-якої цілеспрямованої діяльності, її регуляції, стійкості й ефективності. Професійна психологічна підготовка має реалізуватись шляхом проведення навчальних, практичних занять з використанням інтерактивних технологій і методів навчання (тренінгів, ділових ігор, кейсів, відпрацювання смуг, перешкод тощо). Така підготовка передбачає участь психологів у проведенні цільових інструктажів поліцейських, які направляються для несення служби в екстремальних умовах (зведені загони, що відряджаються до зони проведення АТО, залучаються до охорони публічного порядку під час масових заходів тощо).

Підводячи підсумок, потрібно зазначити, що об'єктивним є співіснування поліцейської підготовки та поліцейської освіти. В умовах реформування $\epsilon$ необгрунтованим руйнування одного зі складників формування професійної компетенції поліцейського. Навпаки, і професійна освіта, і професійна підготовка потребують свого вдосконалення. Суттєві зміни в нашому суспільстві, вимога прозорості та фахової й ефективної правоохо- 
ронної діяльності, зниження корупційних ризиків потребують кардинальних змін у навчальному процесі, розпочинаючи з етапу добору на навчання й завершуючи розподілом. Потреба практики передбачає перехід від формального теоретичного навчального процесу до запровадження тренінгових технологій, особливо в останній рік навчання, формування сталих і професійних навичок.

Необхідно зазначити також, що для якісної підготовки поліцейських в Україні потрібно запровадити в навчальні плани підготовки поліцейських зарубіжний досвід підготовки фахівців для органів поліції.

\section{Jimepamypa}

1. Медведев Ю.Л. Наближення права України до права Європейського Союзу: понятійно-категоріальний апарат та способи узгодження. Вісник Луганського державного університету внутрішніх справ імені E.О.Дідоренка. 2014. № 1. С. 52-59.

2. Користін О.Є. Професійна освіта поліцейського: в якому напрямі рухатись. Концептуальні основи до реформування органів внутрішніх справ як складової правоохоронної систели та сектору безпеки і оборони України. Концептуальні підходи до рефорлування MBC у контексті загальнонаціонального плану рефорл: інформаційно-аналітичні матеріали круглого столу від 16 квітня 2015 р. Київ, 2015. С. 56.

3. Про Національну поліцію : Закон України від 02.07.2015 № 580-VIII. Дата оновлення: 31.08.2018. URL: https://zakon.rada.gov.ua/laws/show/580-.19/ ed20180831 (дата звернення: 07.10.2019).

4. Про затвердження Положення про Національну поліцію : Постанова Кабінету Міністрів України від 28.10.2015 № 877 URL: https://zakon.rada.gov.ua/ laws/show/877-2015-п (дата звернення: 15.10.2019).

5. Про затвердження Положення про організацію службової підготовки працівників Національної поліції України : Наказ МВС України від 26.01.2016 № 50. URL: https://zakon.rada.gov.ua/laws/show/z0260-16 (дата звернення: 15.10.2019).

6. Стратегія розвитку системи Міністерства внутрішніх справ України на період до 2020 року : Розпорядження Кабінету Міністрів України від 15.11.2017 № 1023-р. Дата оновлення: 15.11.2017. URL: https://zakon.rada.gov.ua/rada/show/1023-2017$\%$ D1\% 80\#n2 (дата звернення: 15.10.2019).

\section{Анотація}

Божок С. Г., Медведєва В. С. Професійна освіта поліцейського: напрями реформування (вдосконалення). - Стаття.

У статті розглянуто основні напрями підготовки поліцейських в Україні. На основі аналізу базових нормативно-правових актів запропоновано напрями вдосконалення окремих положень законодавства щодо професійної підготовки фахівців для органів Національної поліції України.

У дослідженні визначаються напрями розвитку підготовки поліцейської освіти відповідно до сучасної законодавчої бази, а саме: Законів України: «Про вищу освіту» і «Про Національну поліцію» - і Стратегії розвитку органів системи Міністерства внутрішніх справ України до 2020 року. Розвиток основних напрямів поліцейської освіти повинен відбуватися згідно із зазначеними в Стратегії цілями у світлі державної політики щодо формування якісно нового підходу до підготовки фахівців правоохоронного органу.

Основними критеріями оцінювання ефективності діяльності поліцейського відомства є такі: дотримання та забезпечення прав людини й основних свобод як ключової цінності в діяльності органів системи MBC; тісна співпраця з територіальними громадами та суспільством загалом; використання успішного міжнародного досвіду і сприяння реалізації пілотних проектів; протидія злочинності й, відповідно, забезпечення національної безпеки за відповідними пріоритетами.

Окремо розглянуто питання щодо видів і напрямів підготовки поліцейських, а також зроблено висновок про необхідність удосконалення та розвитку психологічної підготовки як необхідного елемента сучасної поліцейської освіти.

У підсумках дослідження зазначається про необхідність запровадження психологічної підготовки поліцейських як окремого самостійного виду до системи службової підготовки поліцейських. Професійна психологічна підготовка має реалізуватися шляхом проведення навчальних, практичних занять із застосуванням інтерактивних технологій і методів навчання з використанням передового зарубіжного досвіду.

Професійна психологічна підготовка має на меті розвиток загальних і спеціальних професійних здібностей, знань i вмінь поліцейських i формування системної якості поліцейського - психологічної готовності особистості до професійної діяльності.

Ключові слова: законодавство, законодавча основа, Національна поліція України, професійна підготовка поліцейського, правопорядок, службова підготовка.

\section{Summary}

Bozhok S. G., Medvediva V. S. Professional education of a police officer: trends of reformation (improvement). - Article.

The article deals with the main trends of police officers training in Ukraine. On the basis of the core legal acts analysis, the directions of improvement of the certain legislative provisions regarding professional training of specialists for the bodies of the National Police of Ukraine are proposed.

The study determines the directions of development of police education training in accordance with the current legislative framework, namely the laws of Ukraine: "On Higher Education" and "On National Police" and the Strategy for the Development of Bodies of the Ministry of Internal Affairs of Ukraine until 2020. The development of police education should be in line with the goals set out in the Strategy in the light of state policy on the formation of a new approach to the training of law enforcement officials.

The main criteria for evaluating the effectiveness of the police department are to respect and protect human rights and fundamental freedoms as a key value in the activities of the Ministry of Internal Affairs; close cooperation with territorial communities and society at large; use of successful international experience and promotion of pilot projects; counteracting crime and, accordingly, ensuring national security is prioritized.

The issues of the types and directions of police training are considered separately, as well as the authors conclude that the need to improve and develop psychological training as a necessary element of modern police education.

The results of the study indicate the need to introduce psychological training of police officers, as a separate independent species and to the system of police officers' 
professional training. Professional psychological training should be realized by conducting educational, practical training using interactive technologies and teaching methods using best foreign experience.

Professional psychological training is aimed at the development of general and special professional abilities, knowledge and skills of police officers and the formation of a systematic quality of police - psychological readiness of the individual for professional activity.

Key words: legislation, legislative framework, National Police of Ukraine, professional training of a police officer, law and order, official training. 